\title{
凝縮熱を利用した形状安定化ポリエチレン粒子群の非定常蓄熱特性*
}

\author{
稲 葉 英 男*1, 米田彰*2 \\ 堀 部 明 彦*1, 尾崎 公 一*1
}

\section{The Transient Latent Heat Storage Characteristics of the Shape-Stabilized Polyethylene Pellets by Condensed Heat}

\author{
Hideo INABA, Akira YONEDA, \\ Akihiko HORIBE and Koichi OZAKI
}

\begin{abstract}
This paper deals with the transient heat storage characteristics of high-density polyethylene pellets used as a latent heat storage material by the condensed heat from the ethylene glycol vapor. The polyethylene pellets are fabricated by the shape-stabilization treatment in which the molten pellets maintain the same shape as the solidified ones. The polyethylene pellets packed in the cylindrical heat storage vessel are melted by the condensed heat from the flowing vapor. The effects of vapor temperature, flow rate and the amount of the pellets on the latent heat storage characteristics are investigated experimentally. Moreover, the vapor movement among the packed pellets is enhanced by using the partition plate in the pellets layer. The nondimensional correlation equations of the completion time of heat storage are defined in terms of various nondimensional parameters.
\end{abstract}

Key Words : Heat Storage, Phase Change Material, Polyethylene Pellet, Ethylene-glycol Vapor, Condensed Heat

\section{1. 緒 言}

近年, 特に昼夜間の電力需要格差の增大は, 電力工 ネルギ有効利用の立場から大きな問題となっている. 特に, 夜間電力の有効利用による電力利用平準化を図 る手段として, 電力エネルギの熱エネルギへの変換そ して貯蔵技術に関する関心が増大している。現状の民 生用熱エネルギ貯蔵法において，一般家庭のレベルま で普及しているものは，水の顕熱を利用した温水蓄熱 のみであり，今後一般家庭においても利用可能な蓄熱 システムの開発が望まれるところである。物質の融解・ 凝固に伴う潜熱を利用した蓄熱方法は，水などの温度 差を利用した従来の顕熱蓄熱方法と比較して, 単位体 積当たりの蓄熱量が大きく，また融点近傍のほほ一定 温度の熱出力を得られる特徵を有することなどから， 有望な蓄熱技術である。

この種の潜熱蓄熱に関する従来の研究では, 円筒状 あるいは球状カフセル容器内に, 蓄熱材である有機系 の固·液相変化物質を封入し，その周囲に熱媒体を流 して熱交換を行うカブル型潜熱蓄熱が多く見られる (1)-(3).しかしながら，この種のカブセル型潜熱蓄熱は, カフセル内に蓄熱材を封入させる煩雑さがあり，また カフセル自体が蓄熱材の熱交換の際に大きな熱抵抗と なる問題点がある。このような問題点を克服する蓄熱 材として, 表面架橋処理された形状安定化ボリエチレ ン潜熱蓄熱材が注目されている。形状安定化ポリエチ レンは，それ自身が表面熱抵抗の非常に小さなもので, 蓄熱体は固相形状を維持した状態で, 熱媒体と直接接 触熱交換により融解蓄熱させることが可能となる。神

* 原稿受付 1996 年 2 月 6 日.

*1 正員, 岡山大学工学部 $\boldsymbol{E} 700$ 岡山市津島中 3-1-1).

*2 学生員, 岡山大学大学院.
本ら (4) (5) は，蓄熱体である形状安定化ホリエチレンと 熱媒体を直接接触させて熱交換を行う方法として, 細 長い円柱状蓄熱体群とエチレングリコール熱媒体との 間の潜熱蓄熱に関する報告を行っている。このような 蓄熱方法では，蓄熱完了までに長時間を要することや 熱媒体の流動エネルギー消費が大きいなどの課題が残 されており，この種の蓄熱材に対しては積極的な伝熱 促進法の開発が必要不可欠である。

本研究は, 中温度 $\left(150^{\circ} \mathrm{C}\right.$ 程度)における容積当りの蓄 熱密度の高い急速潜熱蓄熱システムの開発を目的とし たもので，潜熱蓄熱材として表面架橋処理を施した粒 状の形状安定化ボリエチレンを選定し(6)，さらに蓄熱 (融解)速度を増加させる方法として，ボイラーにて発 生したエチレングリコール水溶液からのエチレングリ コール蒸気を粒状蓄熱体充填層に流入そして凝縮させ, その凝縮熱で同ボリエチレンの融解による潜熱蓄熱シ ステムを提案するものである。本潜熱蓄熱システムは, 大気圧レベルで中温度の潜熱および顕熱蓄熱が可能で あり，蓄熱槽の大幅な小型化と蓄熱時間の短縮を図る ことができる。

本報告では，非定常蓄熱特性に影響を及ぼす蓄熱槽 の構造, 熱媒体蒸気温度および蒸気流速等の効果 $(7)$ - (9) を実験的に検討し，その性能を評価したものである。

\section{記 号}

$a$ : 温度伝導率, $C_{p a}$ : 潜熱を含めた見掛けの定王比熱, $C_{p s}$ ： 定圧比熱, $D$ : 試験部容器直径, $d$ : 粒子相当直径, $F o:$ フ リ工数 $\left(=a \cdot \tau_{f} / d^{2}\right), H$ : 蓄熱材充填高さ, $h$ : 比エンタルピ, $L$ :潜熱, $m$ : 質量流量, $Q$ :積算熱量, $q$ : 単位時間当りの熱 量, $R e$ : レイノルズ数 $(=U \cdot d / v)$, Ste : ステファン数, $T$ : 温 度， $t:$ クオリティ， $X$ : 液相中のエチレングリコールの質量分 
率， $Y:$ 気相中のエチレングリコールの質量分率，Cem：エチレ ングリコール水溶夜濃度， $\xi$ :エチレングリコールの質量分率, $\tau$ : 時間, $\rho$ : 密度, $v$ :動粘性倸数

添字 $a$ :平均, $b$ : ボイラ, $c h$ : 蓄熱容器, $f:$ 蓄熱完了, $s t$ : 蓄熱 in : 試験部入口または試験部入の流入, loss：試験部 からの損失， $m:$ 融解，out：試験部出口または試験部からの流 出，':飽和液または凝縮液，" : 乾き飽和蒸気または蒸気，1： エチレングリコール，2:水

\section{2. 蓄熱材および蓄熱方法}

\section{$2 \cdot 1$ 供試蓄熱材の性質本研究で潜熱蓄熱材と} して使用した表面架橋高密度ホリエチレン粒状蓄熱材 の形状写真とその形状寸法を図1に示す。図1に示され 万ように, 粒状蓄熱材平均長径 $d_{0}=3.00 \mathrm{~m} \mathrm{~m}$, 短径 $d_{1}=$ $2.07 \mathrm{~mm}$, 長さ $d_{2}=2.96 \mathrm{~mm}$ のヘレット状で, 粒子の平 均相当直径は $d=3.09 \mathrm{~mm}$ であり，そして粒子 1 個の平 均質量は0.014 gである。尚, 高密度ホリエチレンの表 面は高密度かつ高融点の三次元網目状構造となってお り, 内部のホリエチレンが融解しても，外部へ漏れな い特徵を有するものである。すなわち，表面架橋層は， 数十分子層の薄いもので, 熱抵抗が小さくそして内部 蓄熱材が融解しても固体状態の形状を保つことになる.

四2は，使用したホリエチレン蓄熱材の融解潜熱を 含めた見掛けの比熱 $C_{p a}$ の温度依存性を示したもので あり(8)，融解域が107 - $138^{\circ} \mathrm{C}$ に分散する潜熱分散型 (総融解潜熱 $L=155 \mathrm{~kJ} / \mathrm{kg}$ ) となっている。見掛けの比熱 曲線から単位質量当たりの蓄熱材を初期温度 $T_{0}$ から融 解完了 $\left(T_{f}=138^{\circ} \mathrm{C}\right)$ まで加熱する際に必要となる顕熱と 潜熱を合わせた総蓄熱量は，次のようになる。

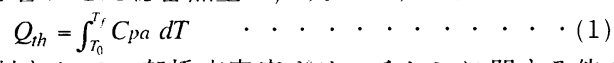

供試材としての架橋高密度ボリエチレンに関する他の 代表的物性值 ${ }^{(4)}\left(20^{\circ} \mathrm{C}\right)$ を以下に示す.

密度 $\rho=948 \mathrm{~kg} / \mathrm{m}^{3}$, 熱伝導率 $\lambda=0.46 \mathrm{~W} /(\mathrm{m} \cdot \mathrm{K})$, 温度

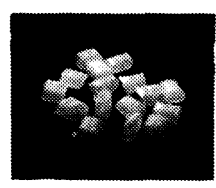

(a) View of pellets

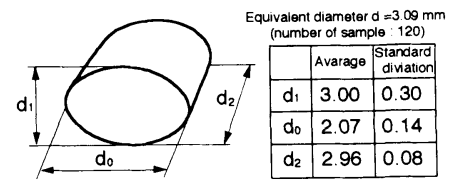

(b) Dimension of pellet
Fig.1 Shape-stabilized high density polyethylene pellets

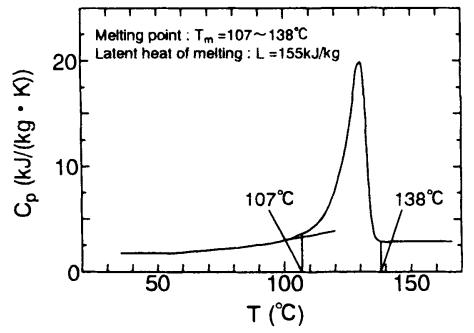

Fig. 2 Specific heat characteristics of polyethylene
伝導率 $a=2.70 \times 10^{-7} \mathrm{~m}^{2} / \mathrm{s}$.

\section{$2 \cdot 2$ 表面架撟高密度ポリエチレン蕃熱材を用いた}

蓄熱方法本研究では，蓄熱速度の増大を得る目的 から，円筒形容器内に充填された供試粒状蓄熱材に， その上方より直接熱媒体蒸気を蓄熱材との接触により 凝縮を起こさせ，その際発生する凝縮潜熱により，供 試潜熱蓄熱材を融解させて, 蓄熱する方法を試みた。

図3は, 粒状蓄熱材の融解過程を模式的に示したも ので, 主たる蓄熱材の融解熱の供給は, 蒸気の凝縮潜 熱によるものである。蓄熱材充填層内を重力方向に流 動するエチレングリコール蒸気は，上流部にある供試 潜熱蓄熱材粒子に接する部分より凝縮し，その蓄熱材 を融解しながら順次下流領域の蓄熱材に向かって進む ことになる。この祭，エチレングリコール蒸気は比較 的均一に蓄熱材粒子群に分散することより，流動抵抗 の小さな状態で上流部より均一な状態で大きな融解速 度を保つことが可能で，蓄熱材全体の蓄熱速度の増大 が図れる。なお，50\%エチレングリコール水蒸気の凝 縮熱は， $L e=1529 \mathrm{~kJ} / \mathrm{kg}$ と大きなものである。また， 凝縮エチレングリコール液は，蓄熱材粒子表面を覆い ながら流下することになる。また，エチレングリコー ル水溶液濃度を変えることにより，任意の温度を持つ 蒸気を得ることが可能である。すなわち，この種の架 橋ボリエチレン融解温度に達するエチレングリコール 蒸気温度は，エチレングリコール水溶液の濃度を変え るだけで，大気圧レベルで得られることになる。

\section{3. 実験装田及び実験方法}

3 ・ 1 実験装思図4は実験装置の概略を示した ものである。実験装置は，主として蒸気発生部として の電気ボイラ(1)，粒状潜熱蓄熱材が充填される円筒状 試験蓄熱槽(2)，蓄熱槽流出凝縮液の計量部(5)，蓄熱槽 流出蒸気の計量部(6)およびこれらを結ぶ管路系から構 成されている。電気ボイラ(1)で発生したエチレングリ コール蒸気は, 蒸気流量計測部(7)を通り試験部(2)へ流 入し, 蓄熱材充填層内の粒状蓄熱材と直接接触しなが ら凝縮し，その凝縮熱により蓄熱材を融解して蓄熱を

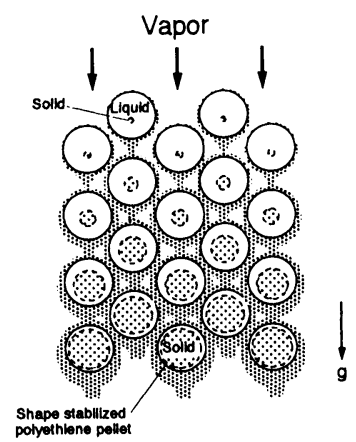

Fig.3 Melting illustration of heat storage layer 
行う。武験部から流出した凝縮液および蒸気は気液分 離器 3 に上り分離され，凝縮液については，その質量 $m_{\text {out.c }}$ の経時変化が電子天科 $(5)$ (分解能0.1 g)にて計測さ れる。一方，繁父については，補助凝縮器(4)で完全に 凝縮させた後，その質量 $m_{\text {out. }}$, の経時変化が電子天秤 6 (分解能 $0.1 \mathrm{~g}$ )にて、汁測される。ボイラ出口の蒸気温度 は，絭線栙0.3 $\mathrm{mm}$ のクロメルーアルメル熱電対 $(1 \mathrm{~mm}$ 径 の保濩管に收納：測定精度士0.1 $\left.{ }^{\circ} \mathrm{C}\right) に よ り$ 測定され， ボイラ内の片うおよび武験部出人口圧力は，ブルドン 管式速成性力胡を用いて測定される。尚，用いた压力

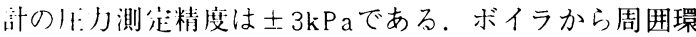
境へ放出される熱損失は，ボイラ外壁に張り付けられ た熱流果セン少(測定精度士2\%)により測定される。ま

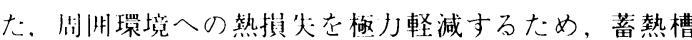
を除く活济全ての管路系に設けたニクロム線ヒータで 保温し、さらに装置食体在孛さ100 $\mathrm{mm}$ のグラスウール 断熱材で復ってある。

刚うは、試験部の絴紼をポしたものである。試験部 器器はステンレス锎製であり, 内直径 $D_{c h}=$ $100.0 \mathrm{~mm}$, 省さ $H_{c h}=568.0 \mathrm{~mm}$, 肉厚 $t_{c h}=0.8 \mathrm{~mm}$ の円 简樀分と、その!: 部および下部で外径 $D_{0}=19.05 \mathrm{~mm}$, 内栙 $D_{i}=17.05 \mathrm{~mm}$ の錩管につながる円錐状部分および これら，芯挍悀させるフランジ部などから構成されてい る。们简試験蔀のト㰾には，粒状潜熱蓄熱材保持のた めのステンレス鍓製ワイヤーメッシュ（１000，素線 忙柊 $d=0.2 \mathrm{~mm}$ )が没けられている。粒状潜熱蓄熱材は,

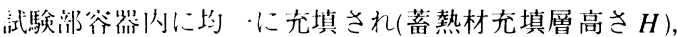

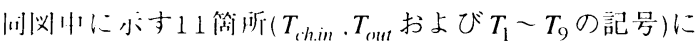

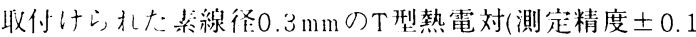
C)によーて、蓄熱槽内温度及び試験部入口・出口蒸気 温度 $T_{\text {ch }, i n}, T_{o u t}$ が测它されれ。尚，蓄熱材充填層と試験 䢼内辟とに形成された閏隙から流出する蒸気を遮断す

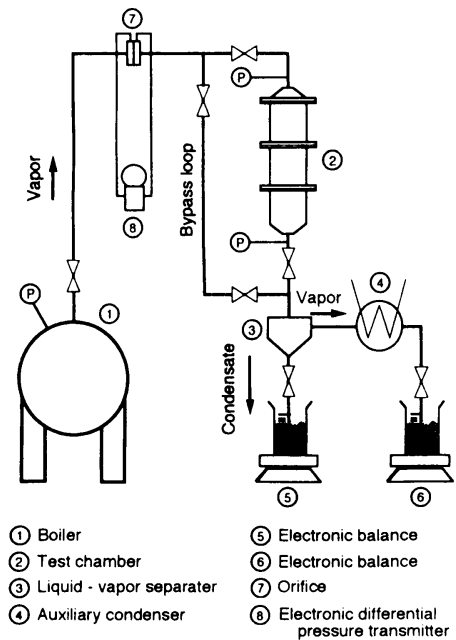

Fig.4 Schematic diagram of experimental apparatus
るため，試験部底に幅 $5 \mathrm{~mm}$ 当ンング状テフロンシート が敷かれてある。試験部容器への入熱量 $Q_{c h}$ (顕熱量)は, 試験部外壁内に等間隔に埋め込まれた9本の素線径 $0.3 \mathrm{~mm}$ の銅一コンスタンタン熱電対による温度測定值 をもとに算出する。試験部から周囲入放出される熱量 は，試験部側面外壁の三筫所に取り付けられた熱流束 センサ(測定精度 $22 \%$ )の測定値をもとに算出する。各 熱電対の熱起電力及び電子天秤からの電気信号は, 測 定時間間隔 $\tau=15 \mathrm{sec}$ ごとにデータ収録システム(分解 能 $1 \mu \mathrm{V})$ を介してコンヒュー夕にて自動収録され，実 験終了後にデータの整理及び解析を行った。

$3 \cdot 2$ 蒸気流量の計測法試験円筒容器部入流入 する蒸気流量は，図4の(7)、(8)に示す位置にオリフィス と電子式差王発信器を組み合わせた微小蒸気流量計測 システムを開発することにより測定した。高温蒸気に 対する電子式差圧発信器のセンサ保護の為, 配管内に あらかじめ油系のシール液を満たしてオリフィス前後 の差圧を測定することにした。また，導圧管の配管方 法を検討した結果，リザーバタンクにより液位が常に 一定となるように工夫を施した。配管には二クロム線 ヒータを巻き, そのヒータ出力制御による温度調節か ら計測配管系内の蒸気の凝縮を防止している。本蒸気 流量計測システムの測定精度は, 蒸気を凝縮させてそ の質量測定結果と比較して $\pm 3 \%$ 以内で一致していた。

$3 \cdot 3$ 実験方法実験に先立って, 実験装置全体 の管系を真空ホンフにより十分真空にした後，ボイラ 内の電気ヒータに入力し，蒸気の発生を開始する。ボ イラ内の圧力が大気圧以上になったところで，ボイラ 出口バルブを開けバイハスルーフに蒸気を流す。ボイ ラの電気ヒーター入力を制御することで蒸気流量を設 定する。蒸気流量が十分安定した後，一時的に電子天 秤(5)、6の上方のバルブを閉じ，蒸気流をバイバスルー

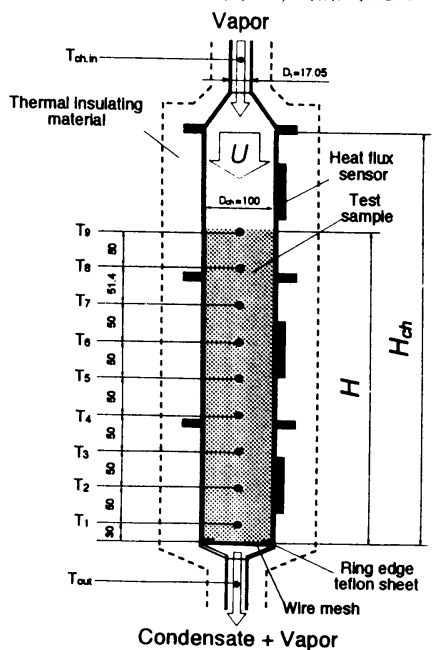

Fig. 5 Detail of test section 
フから試験部蓄熱槽へバルブを切り換え，蓄熱実験を 開始する。さらに, 試験部出口蒸気圧力が大気圧程度 に達したことを確認し，一時的に閉じておいた電子天


試験部入口蒸気温度がボイラ温度にほぼ等しくなるよ うに，配管に巻かれたニクロム線ヒータへの電気入力 を手動にて微調整する。試験部入口蒸気温度と試験部 出门蒸気温度の時間的変化が等しくなった時点で実験 を終了寸る。実験は，蓄熱特性に及汸寸因子として 試験部容器空塔流速 $U$, 入口蒸気温度 $T_{\text {ch.in }}$, 粒状潜熱 蓄熱材充填高さ $H$ を取り挙げ, 以下の上うな条件で行っ た。後述子る粒子充填層内に仕切板を挿入した場合の 実験もほ汪同様の条件で行った。試験部容器内空塔流 速 $U=4.2 \times 10^{2} \sim 22.5 \times 10^{-2} \mathrm{~m} / \mathrm{s}$, 蓄熱材充填層入口 蒸父温度 $T_{\text {ch.in }}=133.0 \sim 165.0^{\circ} \mathrm{C}$, 蓄熱材充填層高さ $H=9.50 \sim 42.0 \mathrm{~cm}$ ，蓄熱材充填層高さ(仕切板挿入) $H=10.7 \sim 45.7 \mathrm{~cm}$.

\section{4 実験結果および考察}

$4 \cdot 1$ 各要素における熱量の算出方法 単位時間 当りの蓄熱材の顕熱と潜熱の総蓄熱量 $q_{s t}(\mathrm{~W})$ は, 次式 より算出した。

$$
q_{s t}=q_{\text {in }}-q_{\text {out }}-q_{\text {ch }}-q_{\text {loss }}
$$

ここで, $q_{\text {in }}$ : 試験部への流入エンタルヒ, $q_{\text {out }}$ : 試 験部加のの流出エンタルヒ, $q_{\text {ch }}$ : ステンレス銅製容器 への顕熱蓄熱量, $q_{\text {loss }}$ : 熱損失量である。また, 各熱 量の積算値は時間 $\tau$ で積分し, $Q_{i n}\left(=\int_{0} q_{i n} d \tau\right), Q_{o u t}$ $\left(=\int_{0} q_{o u t} d \tau\right), \quad Q_{c h}\left(=\int_{0} q_{c h} d \tau\right), \quad Q_{\text {loss }}\left(=\int_{0}^{0} q_{\text {loss }} d \tau\right)$ で表し, 蓄熱材への総積算蓄熱量 $Q_{s t}(\mathrm{~kJ})$ は, 次の上うになる。

$$
Q_{s t}=\int_{0} q_{s t} d \tau=Q_{i n}-Q_{o u t}-Q_{c h}-Q_{\text {loss }}
$$

また、試験部の入口及び出口に関して，二成分(エチ レングリコールと水気液相平衡状態とすると, 熱媒体 の状態量が決定できる。すなわち，質量分率 $\xi$ の湿り 蒸気の温度が $T$ であった場合のクオリティ $t$ は, 次の ようになる。

$$
t=\frac{X-\xi}{X-Y}
$$

ここで， $X$ および $Y$ は飽和液及び飽和蒸気における エチレングリコールの質量分率である。一方，飽和液 及び乾き飽和蒸気の比エンタルヒ(基準温度を $\left.0^{\circ} \mathrm{C}\right)$ をそ れぞれh'、ん゙とすると、

$$
\begin{aligned}
& h^{\prime}=h_{1}^{\prime} X+h_{2}^{\prime}(1-X) \\
& h^{\prime \prime}=h_{1}^{\prime \prime} Y+h_{2}^{\prime \prime}(1-Y)
\end{aligned}
$$

であり，添字1及び添字2はそれぞれエチレングリコー ル及び水を, 添字なしは混合物の状態を表す。尚, 実 験中の試験部圧力が大気圧にほ活等しい $(0.1 \mathrm{MPa})$ こと より，上記の計算に必要な圧力は大気圧としてある。 そして, 単位時間当たりの熱量 $q(\mathrm{~W})$ は質量流量 $m$ から 次のようになる。 $q=m(1-t) h^{\prime}+m t h^{\prime \prime}$

上記の式(4)〜 (7)を試験部人口及び出口に適用すること により， $q_{\text {in }}$ 及び $q_{\text {out }}$ を求める。ここで，エチレングリ

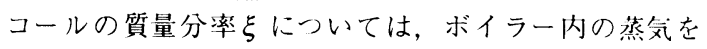
乾き飽和蒸気として, 温度の測定值から求めた。また, 入口の質量流量 $m_{i n}$ は, 人口蒸気流量計測装置から, 得ら れる測定値を用いてある。出口蒸気および液の質量流 量 $m_{\text {out }}$ は, 電子天秤で測定した蒸気及び凝縮液の質量 流量 $m_{\text {out. }}, m_{\text {out. }}$ の和を用いてある。

\section{$4 \cdot 2$ 蓄熱槽内の温度分布と蓄熱量の経時変化}

図6(a) は, 平均空塔流速 $U=4.03 \mathrm{~cm} / \mathrm{s}$, 平均人儿蒸 気温度 $T_{\text {ch.in }}=144.2^{\circ} \mathrm{C}$, 蓄熱材旮填層高さ $H=32.5 \mathrm{c} \mathrm{m}$ および蓄熱槽初期温度 $T_{0}=35^{\circ} \mathrm{C}$ の条件におけ万蓄熱槽 内の各測定点温度の経時変化を小したものである。蓄 熱槽入口でのエチレングリコール蒸気の温度 $T_{\text {ch.in }}$ は, 実験開始直後数分で急激に上㧛した後，・時的に低下 しているが，これは実験開始直後に起こる真空状態に あ万試験部内に急激に蒸気が流人するため，装置内の 蒸気の圧力降下に伴って蒸㕮の館和温度が低下寸万た めと考えられる。兴の後, これらの温度は实験開始か ら10〜15分程の比較的短時間でほぼ-...定の值と交る。 蓄熱材充填層内の各点の温度は, 実験開始直後, 試験 部入口から蒸気の流れ方向の順に，110 $\mathrm{C}$ 付近まで急 激に上昇した後 $120 \sim 130^{\circ} \mathrm{C}$ 付近まで緩やかにト年し， 再び急激に充填層人口温度まで上:萛しており，潜熟蓄

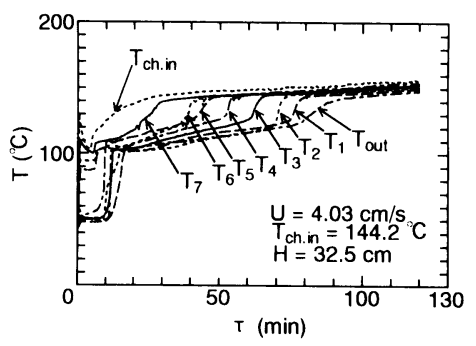

(a) Temperature

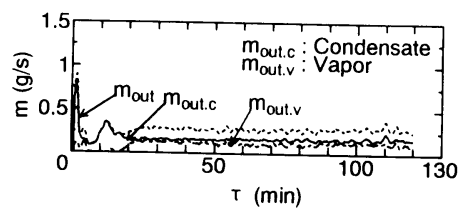

(b) Mass flow rate

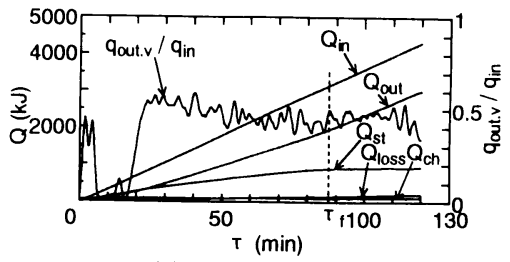

(c) Integrated energy

Fig.6 Time history of temperature, mass flow rate and integrated heat energy 
熱材の融解が蓄熱槽上部より下部へと徐々に進行して いく様子が伺える。このような温度上昇の変化は, 図 2で示されたように蓄熱材である高密度ボリエチレン の融解潜熱の温度領域が分散型をとるためと考えられ る。図6(b)は，図6(a)と同一実験における蓄熱槽より流 出した凝縮液および蒸気の質量流量 $m_{\text {out.c }}, m_{\text {out.v }}$ の経時 変化を示してある。図中の $m_{\text {out }}$ は， $m_{\text {out.c. }}$ と $m_{\text {out } . v}$ を合 計した総排出量である。実験開始直後から凝縮液の排 出が見られ，※して約20分後から試験部より多くの蒸 父が流出していることが観察される。この現象から， 実験開始から約20分までは多量の蒸気が試験部内で疑 縮し, その凝縮熱で蓄熱材の融解が行われ，約 20 分後 より槽内に停留する凝縮液の熱抵抗や蓄熱材温度上昇 による交換熱量の減少から, 排出される蒸気量が増大 寸万ものと思われる。また，凝縮液および蒸気の流出 量の変動は, 槽内に停留する凝縮液が蒸気流路を狭め ることによる蒸気压の増大(ボイラ出力一定)により, 凝縮液の槽外への排出が行われる現象が間欠に行われ るためである。図6(c)は, 各積算熱量そして流入エン タルヒ $q_{\text {in }}$ に対する蓄熱槽流出蒸気エンタルヒ $q_{\text {out.v }}$ の割

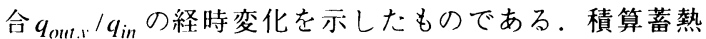
量 $Q_{s t}$ は時間の経過とともに増加し, ある一定の熱量に 漸近していくことがわかる。また，流入エンタルビ $q_{\text {in }}$ と流出蒸気エンタルヒ $q_{\text {out.v }}$ の割合 $q_{\text {out } . v} / q_{\text {in }}$ は，実験開 始直後はほぼ零であるが，その後急激に上昇した後約 0.4〜0.6の值で推移している。ここで，蓄熱完了時間 $\tau_{f}$ は, 潜熱蓄熱材の融解終了温度まで蓄熱した場合の 理論的に必要な熱量 $Q_{t h}$ (式(1)参照)の99\%に達した時間 と定義してある。

汹7は, さらに大きい蒸気流速の平均空塔流速 $U=$ $8.74 \mathrm{~cm} / \mathrm{s}$, 平均入口堂気温度 $T_{c h . i n}=143.8^{\circ} \mathrm{C}$, 充填層 离さ $H=32.5 \mathrm{~cm}$ の条件における蓄熱槽内温度, 排出蒸 気や凝縮液量として各積算熱量の経時変化を示したも のである。試験部空塔流速 $U$ が遅い図6(a)の場合と比 較して，网7(a)の $U$ の大きい場合には，蒸気の流れ方 向に对して温度上昇の時間幅が小さく，短時間で蓄熱 が䒚了していることがわかる。これは，空塔流速が大 きくなる活ど流入熱量の増加とともに，蓄熱材を覆っ た液膜に作瑚する剪断力が強くなるため，液膜が薄く なり, か一凝称液の排出も促准され, 結果として蒸気 と蓄熱材の熱伝详が向上したためと考えられる。図7 (b)では，図6(b)と比較して試験部流出蒸気が流出凝縮 液よりもに回っていることが観察される。また, 図7 (c)にホすように $q_{\text {out } .} / q_{\text {in }}$ が約 $0.5 〜 0.7$ と大きいことか ら，㯚気流速の増大によって蓄熱材と蒸気の熱伝達は 问上されるが，十分に凝縮潜熱を放出しないで蓄熱層 芷通過していくことが伺える。
図8は, 入口蒸気温度を $T_{\text {ch.in }}=151.5^{\circ} \mathrm{C}$ に上昇した場 合の蓄熱槽内温度, 排出蒸気や凝縮液量および各積算 熱量を示したものである。図8(a)に示すように，蓄熱

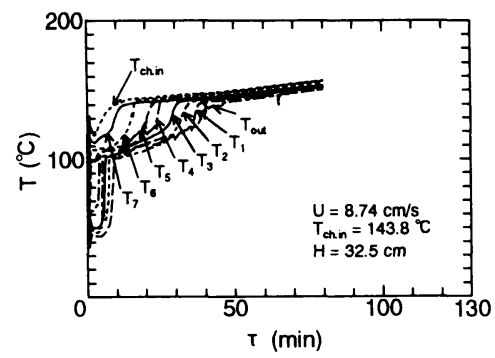

(a) Temperature

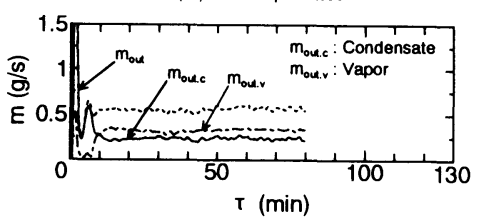

(b) Mass flow rate

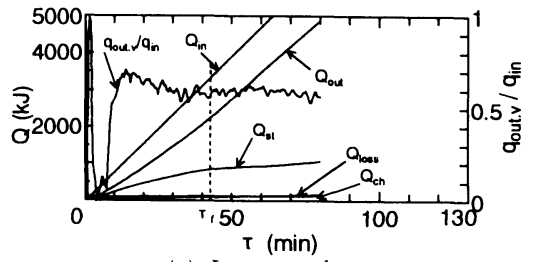

(c) Integrated energy

Fig.7 Time history of temperature, mass flow rate and integrated heat energy

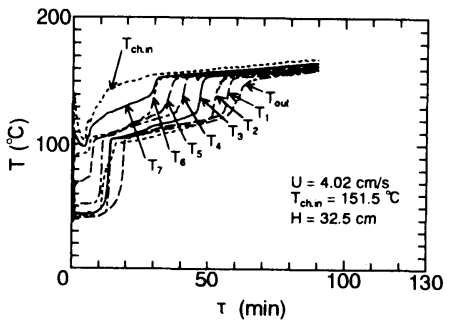

(a) Temperature

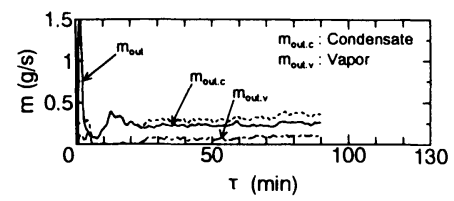

(b) Mass flow rate

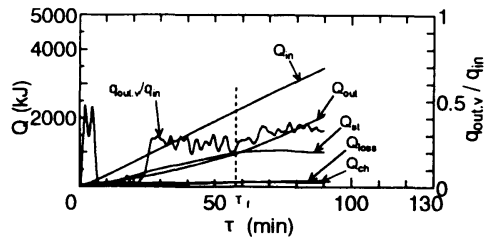

(c) Integrated energy

Fig. 8 Time history of temperature, mass flow rate and integrated heat energy 
槽各点の温度は，蓄熱材の潜熱温度領域 $\left(107 \sim 138^{\circ} \mathrm{C}\right)$ 在比較的短時間で上昇し，早期に蓄熱槽入口蒸気温度 に近付く傾向となる。四8(b)に見られるように，蓄熱 槽から流出する凝縮液に比べ, 流出する蒸気は減少す ることがわかる。また，図8(c)に示すように， $q_{\text {out.v }} / q_{\text {in }}$ は約0.2 0.4 と推移し，入口蒸気温度の低い図6の場合 より小さな值となっている。このことより，入口蒸気 温度の上昇は蓄熱材への入熱を促進するとともに蒸気 の凝絔潜熱を十分に蓄熱槽内で放出し, 効率の良い蓄 熱をもたらすことになる。

$4 \cdot 3$ 蓄熱材充填層形状の経時変化実験を十数 回繰り返した後, 試験部容器内を観察したところ, 図 9で示すように, 蓄熱材充填層は融解・凝固の繰返し によって円筒形状を維持したまま,その直径が容器内 径より2〜4 mm 程度収縮していることが観察された。 これは，ホリエチレン粒子の融解時の体積膨張が大き く, 粒子同土が圧縮され固着し, 融解時の形状のまま 泠却され収縮するためと考えられる. 円筒形状に固まっ た蓄䏵材充填層の形成により，蒸気はその充填層と円 筒蓄熱槽の隙間を主として流れるようになり，結果と して効率的な蓄熱が行えない状態となる。なお，後述 の仕切板を設けない場合の実験整理式(11)は，十数回 の融解・凝固を繰り返した後の蓄熱材形状の安定した 状態の実験值より求めたものである。従って, 種々の 形状の仕切板の検討をした結果，図10に示すような簡 便な構造の断面形状を持つステンレス鋼製のメッシュ (\#1000, 素線径0.2 $\mathrm{mm}$ )に上万仕切板を充填層内に挿 入し，蓄熱材充填層内に積極的に間隙をつくることに より，蒸気及び凝縮液の流路を確保する検討を行った。 仕切板の配置は, 分割される蓄熱粒子群の各ブロック 周辺長さがほぼ同じになるようにした場合に，最短の 蓄熱完了時間を得たことにより，図10(b)に示す仕切板 配置とした。なお，仕切板への顕熱蓄熱量は，相対的 に全蓄熱量に対し $5 \%$ 以内である。

\section{$4 \cdot 4$ 蓄熱槽内の温度分布と蓄熱量の経時変化にお} ける仕切板の影響図11は, 仕切板を扦入し10回以 上の蓄放熱の繰り返した後の蓄熱材充填層において, 図6の場合と同じ実験条件における諸值の経時変化を 示したものである。図11(a)に示すように，実験初期に おいて蓄熱材充填層全体に急激な温度上昇が観察され る。これは，10回以上の蓄熱の繰り返しにより，複数 の仕切板に沿って蓄熱材層との間にできた間隙に蒸気 が通り报け万効果によるものと思われる。また，蓄熱

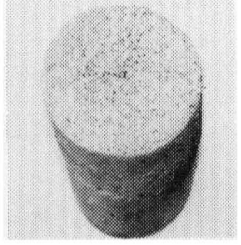

Fig.9 View of pellets taken from the test chamber
材充填層内の各温度が蒸気の流入部から順に上昇して おり, 蓄熱材の融解が徐々に下部に進行していく様子 がわかる。ここで，蓄熱槽の蒸気出口温度 $T_{\text {out }}$ に着目 すると, 充填層下部の温度よりも宫くなっていること が観察される。これは，一部の蒸気が蓄熱材と十分に 熱交換されないままに流出していることによる。四11 (b)の蓄熱槽入口部蒸気流量 $m_{i n}$ は，実験初期において 蒸気の流入が若干停滞し，蒸気流れが不安定となるこ とが認められる。これは，蓄熱材と蒸気の大きな温度 差のために，蒸気が瞬時に凝縮液となり，その凝縮液 が蓄熱材粒子間又は金網メッシュに保持され，流入蒸 気に対して大きな流動抵抗となっていることによる。 図11(c)の $q_{\text {out.v }} / q_{\text {in }}$ は, 実験開始直後は零であり, その 後0.6〜0.7と高い值を示すが，実験中半からは蒸気の 流入が安定しており， $q_{\text {out.v }} / q_{\text {in }}$ は，金網メッシュの無 い図6の結果と比較して0.4付近で推移することより, 金網メッシュの挿入は蓄熱材充填層内の蒸気の流入促 進と凝縮液排出促進による効果が現れたものと考えら れ，蓄熱完了時間の短縮となることがわかる.

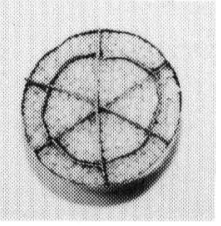

(a) View of partition

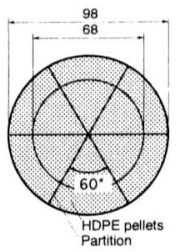

(b) Dimension of partition



(a) Temperature

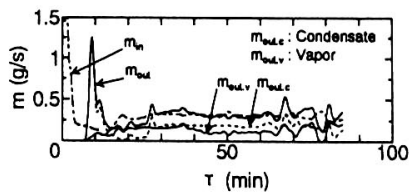

(b) Mass flow rate

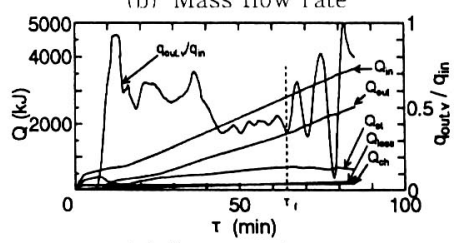

(c) Integrated energy

Fig.11 Time history of temperature, mass flow rate and integrated heat energy 


\section{4 -5 蓄熱完了時間の無次元整理本実験では,} 同一断面積を有する円筒蓄熱槽内に充填される粒状蓄 熱材の質量の大小によって充填層高さ $H$ を決定してい るため，Hの高さにより総蓄熱容量が異なる。このた め形状安定化ホリエチレン潜熱蓄熱槽の蓄熱完了まで の時閂 $\tau_{f}$ を次元解析より無次元時間であるフーリ工数 Foで表し，蓄䓡究う時間に及ぼす因子として，レイノ ルズ数 Re，顕熱と潜熱の比であるステファン数Ste と 無次匹允填層高さH/dに分割して，それぞれの影響に ついて整理を行った。ただ，仕切板を挿入した蓄熱 槽と什切极在没けない蓄熱槽による実験結果とは別々 に整理在行つた。ここで，备無次元数の定義はそれぞ れ次式とした。

フーリエ数： $F_{0}=\frac{a \cdot \tau_{f}}{d^{2}}$

レイノルズ数: $R e=\frac{U \cdot d}{v}$

ステファン数 : Ste $=\frac{\int_{T_{0}}^{T_{t}} C_{p s} d T}{L}$

网12は，仕切板を設けない場合において無次元充填

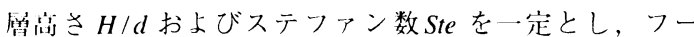
リエ数Fo とレイノルズ数Reの関倸を示したものであ る。㭎12に上り，间・の無次元充填層高さ $H / d$ および ステンッン数 Ste のもとでは, $R e$ 数の増加はFo 数の減 少すなわち触解促准となることが理解でき，これらの 間には $F o \times R e^{-1.2}$ の関倸がある。図13は，レイノルズ 数 $R e$ および無次元充填層高さ $H / d$ を一定とし，フーリ 工数 Fo とステファン数Steの関係を示したものである。 刚13より，|i门] のレイノルズ数 Reおよび無次元充填層 点さH/dのもとでは，ステファン数Ste の増加はフー リ工数Foが著しく減少寸る結果となる。す寸なわち流入

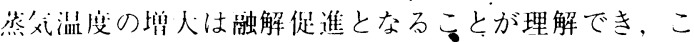
扎らの間には $F o \times S t e^{-6.7}$ の関倸がある。四14は。レイ ノルズ数Reおよびステファン数Ste を一定としたとき のフーリエ数 $F o$ と無次元充填層高さ $H / d$ の関倸を示し たものである。网14より，同・のレイノルズ数Reおよ びステンァン数 Ste のもとでは, 無次元蓄熱槽高さ $H / d$ の增大はフーリエ数Fo の増加となり, $F_{0} \times(H / d)^{1.2}$ の関倸がある。以上に述べた各無次元八 ラメータのフーリエ数 Foへの影響をもとに最小二乗法 を用いて，什划柀無しの本実験デー夕を標準偏差士12 \%にて近似する次の実験整理式を得た。

$$
F o=1.8 \times 1\left(^{3} \cdot \operatorname{Re}^{-12} \operatorname{Ste}^{-6.7}(H / d)^{1.2} \quad \cdots(11)\right.
$$

ただし、年式の適用範囲は， $R e=7.9 \sim 22.6, S t e=$ 1.86 - 2.23， H/d=31.7〜140.0である。

次に，蓄熟槽に前述の仕切板を㨂入することにより 充埧層内部への熱移動の促准を図り，前述の場合と同 様に，得られた実験結果をもとに仕切板を挿入した場 合の無次元整理を行った。図15は，無次元充填層高さ $H / d$ およびステファン数Ste を一定とし，フーリエ数
Fo とレイノルズ数 Re の関係を示したものである. 図 15 より，フーリエ数 Fo とレイノルズ数 Re との間には $F o \propto R e^{-0.98}$ の関倸となり，仕切板を挿入しない蓄熱槽 の図12の場合よりもフーリ工数Foに対するレイノル ズ数 $R e$ の寄与割合は減少している。これは, 仕切板の 挿入により充填層内における凝縮液の排出が促進され, 凝縮液による流動抵抗を軽減し，低レイノルズ数にお いてフーリエ数Foの低減が目立ったためと考えられる。 図16は，レイノルズ数 Re および無次元充填層高さ $H / d$ を一定とし, フーリエ数 Fo とステファン数 Ste の 関係を示したものである。図16より，フーリエ数Fo とステファン数 Ste との間にはFo $\propto S t e^{-3.8}$ の関係となり, 図13の仕切板無しの場合よりもフーリ工数Foに対す るステファン数Steの寄与割合は減少する結果となった。 また，フーリエ数 Fo の低隇はステファン数 Ste が小さ いときほど良く現れており，凝縮液の排出促進による 蓄熱材充填層内の熱抵抗の軽減効果があるものと考え られる。図17は，レイノルズ数 Re 拉よびステファン数 $S t e$ を一定としたときのフーリエ数 Fo と無次元充填層

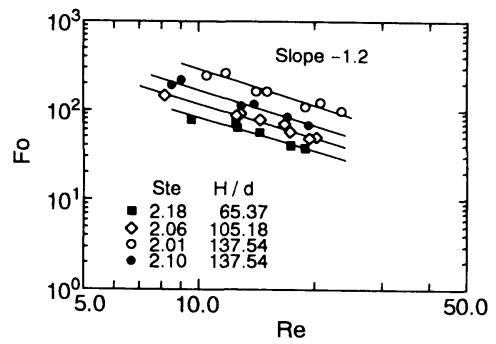

Fig.12 Relationship between $F o$ and $R e$ without partition

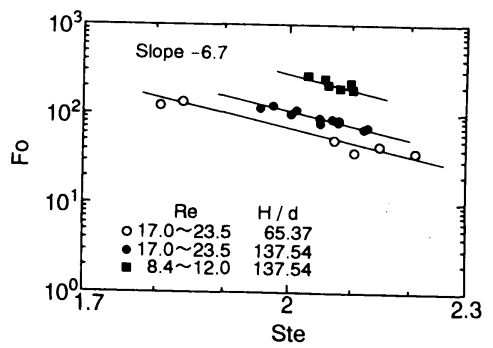

Fig.13 Relationship between Fo and Ste without partition

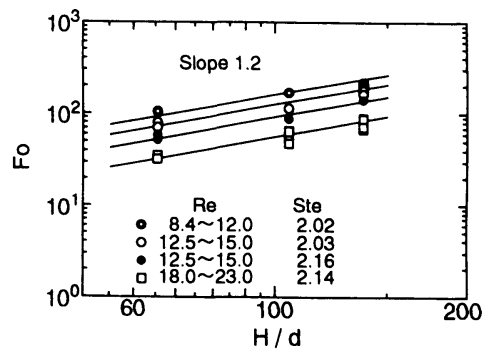

Fig.14 Relationship between $F o$ and $H / d$ without partition 
高さH/dの関係を示したものである. フーリエ数 Fo と 無次元充填層高さ $H / d$ との間には $F o \propto(H ! d)^{0.92}$ の関係 となり，仕切板を挿入したことによるフーリエ数 Foの 低減は, 無次兀充填層高さ $H / d$ が大きい場合に顕著で あり，主に蒸気の流れ方向における流動抵抗の軽減効 果があるものと考えられる。蓄熱槽に仕切板を挿入し た場令において，以上に述ベたフーリエ数Foに対する 各ハラメータの影響を含めた実験整理式(12)を最小二 采法にて標準偏差士14\%で誘導した。図18は，フーリ 工数Fo と各八ラメータとの関倸を示したもので，実線

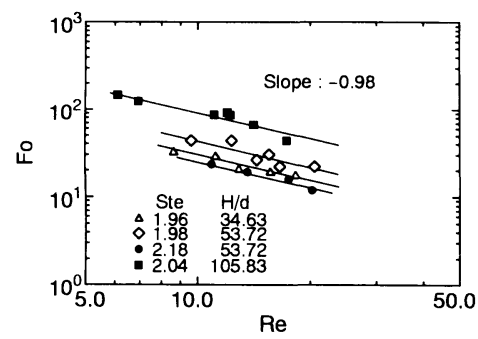

Fig.15 Relationship between $F o$ and $R e$ with partition

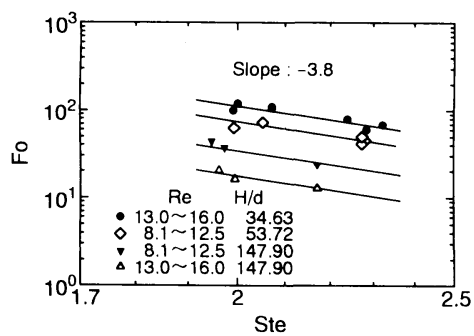

Fig.16 Relationship between Fo and Ste with partition



Fig. 17 Relationship between $F o$ and $H / d$ with partition

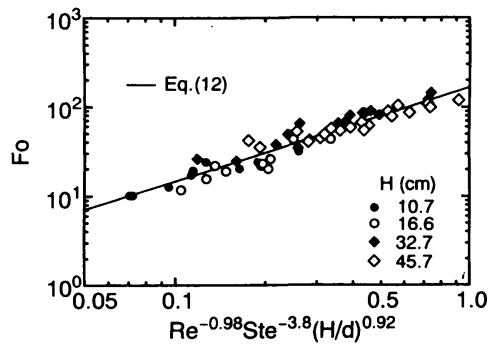

Fig.18 Variation of Fo with $\operatorname{Re}^{-0.98}$ Ste $e^{-3.8}(H / d)^{0.92}$
は式(12)に基づくものである。

$$
F o=1.7 \times 10^{2} \cdot \operatorname{Re}^{-0.98} S_{t e}^{-3.8}(H / d)^{0.92} \quad \cdots .
$$

ただし, 上式の適用範囲は, $R e=6.4 \sim 26.1$, Ste $=$ $1.89 \sim 2.34, H / d=34.6 \sim 147.9$ である。

\section{5. 結 論}

表面架橋形状安定化粒状ボリエチレン潜熱蓄熱材の 融解現象を利用した新しいタイブの潜熱蓄熱方法の検 討を行った。熱媒体としてエチレングリコール蒸気の 凝縮に伴う凝縮熱による表面架橋形状安定化粒状ボリ エチレン潜熱蓄熱材の融解を, その蓄熱完了時間に及 ぼす蒸気流速, 人口蒸気温度, 充填層高さおよび蓄熱 槽の構造の影響を実験的に検討し，次のような結論を 得た。

（1）エチレングリコール蒸気の凝縮熱を利用した粒状 ボリエチレン充填円筒型蓄熱槽における非定常蓄熱挙 動が定量的に明らかとなった。すなわち, 熱媒体蒸気 の蓄熱槽流入温度および流入速度の増大に伴って,よ り短時間に蓄熱が進行する。しかしながら，効率的な 蓄熱の点から蒸気の凝縮潜熱の放出による熱交換は, 蒸気温度が高いほど良好となり，一方，蒸気流入速度 が大きいほど蓄熱槽内で効率的な凝縮が得られないこ とが判明した。

(2) ボリエチレン蓄熱材充填円筒型蓄熱槽で蓄熱材の 融解・凝固の繰り返しによって, その蓄熱材粒子層は 円筒形状を維持したまま固着し，その直径が $2 \sim 4 \mathrm{~mm}$ 程度収縮することが判明した。蒸気はその充填層と円 筒蓄熱槽の隙間を主として流れるようになり，結果と して効率的蓄熱が行えない状態となる。

(3) 粒状ホリエチレン充填蓄槽内の蒸気及び凝縮液の 流路確保に設けた複数の仕切板は，仕切板を設けない 蓄熱槽の場合と比較し，蓄熱完了時間の短縮となるこ とが明らかとなった。

(4) 潜熱蓄熱特性に及ぼす熱媒体蒸気温度および流速 や蓄熱材充填量の影響について定量的に明らかにし， 蓄熱完了時間に及ぼす各実験ハラメータの効果が無次 元整理式の形で表すことができた。

\section{参考文献}

(1) 伊藤, 機論, 50,450, (昭59-2), 556 .

(2) 平田 - 植田, 機論, 53,485, (昭62-1), 204.

(3) 菊池. ほか3名, 化学, 16-5(1990), 982.

(4) 神本・ ほか 7 名, 電子技術総合研究所研究報告, No.850(1984)

(5) 宮武・ ほ名 2 名, 空気調和衛生工学会論文集, No.48(1992-2), 49.

(6) 稲葉・ほか2名、機講論, No.915·1(1991·3), 139.

(7) 稲葉・ほか2名、機講論, No.945-1(1994-3), 126.

(8) 稲葉・泳33名, 第29回伝熱シンボジウム講論, (1992). 789 .

(9) 稲葉・ほか2名, 第32回伝熱シンボジウム講論, (1995-5), 461. 